\title{
ЗНАЧЕННЯ ДИСЦИПЛІНИ ОСНОВИ МЕДСЕСТРИНСТВА» У ФОРМУВАННІ ПРОФЕСІЙНИХ КОМПЕТЕНТНОСТЕЙ СТУДЕНТІВ МЕДИЧНОГО КОЛЕДЖУ
}

\author{
Н. Ю. Лучишин ${ }^{1}$, Л. А. Огарьова ${ }^{2}$ \\ ${ }^{1}$ Тернопільський національний медичний університет \\ імені І. Я. Горбачевського МОЗ України \\ ${ }^{2}$ Кременчуцький медичний фаховий коледж ім. В. І. Литвиненка
}

\begin{abstract}
У статті проаналізовано вплив вивчення основ медсестринської діяльності на формування професійних компетентностей майбутніх медичних сестер у процесі освоєння дисципліни «Основи медсестринства", яка включає історію, теорію і філософію медсестринської справи, вивчення функціональних обов'язків медичної сестри стаціонару, характеристику етапів медсестринського процесу, особливості спостереження і догляду за пацієнтами з певними порушеннями.
\end{abstract}

\section{THE IMPORTANCE OF THE DISCIPLINE «FUNDAMENTALS OF NURSING» IN THE DEVELOPMENT OF PROFESSIONAL COMPETENCIES OF NURSING STUDENTS'}

\author{
N. Yu. Luchyshyn ${ }^{1}$, L. A. Oharyova ${ }^{2}$ \\ ${ }^{1}$ I. Horbachevsky Ternopil National Medical University \\ ${ }^{2}$ V. I. Lytvynenko Kremenchuk Medical Professional College
}

\begin{abstract}
The article analyzes the influence of studying of basic nursing skills on the formation of professional competencies of future nurses in the process of mastering the discipline "Fundamentals of Nursing", which includes history, theory and philosophy of nursing, understanding of functional responsibilities of a nurse, characteristics of nursing processe, observation and care for patients with certain disorders.
\end{abstract}

Вступ. Проблема формування професійної компетентності майбутніх медичних сестер особливо актуальна на сьогодні, про що свідчить теоретичний аналіз наукової літератури. Саме з формуванням компетентності пов'язана якість професійної освіти майбутнього фахівця, що забезпечує його конкурентоспроможність на ринку праці. Перехід на компетентнісно орієнтовану освіту став закономірним етапом модернізації стандарту професійної освіти [1-3]. Його реалізація передбачає створення акцентів на високому рівні сформованості фахових знань, умінь і навичок, творчого мислення, життєвих цінностей студентів.

Основна частина. Професійні кваліфікаційні вимоги, які встановлені перед випускниками медичних навчальних закладів, визначаються галузевими стандартами вищої освіти України як перелік умінь і навичок розв'язання завдань професійної діяльності.

() Н. Ю. Лучишин, Л.А. Огарьова, 2021
3 огляду на це, зміст сучасної підготовки за спеціальністю «Медсестринство», спеціалізацією «Сестринська справа» представлений у нормативній моделі компетентності - освітньо-кваліфікаційній характеристиці, яка відображає науково обґрунтований склад професійних знань, умінь і навичок.

Компетентність (від лат. «соmpete»- змагатися, конкурувати) включає два аспекти: з одного боку коло повноважень, наданих законом, з іншого - знання чи досвід у певній галузі. Саме таких фахівців, які володіють комплексом знань, умінь, навичок і компетенцій, необхідних для їх професійної діяльності, повинні готувати медичні навчальні заклади, створюючи оптимальні умови для реалізації потенціалу молодого фахівця охорони здоров'я. Поняття «компетентність» складається з великої кількості компонентів, за різними дослідженнями їх налічується від 15 до 30 і більше [4-6]. Відповідно до Державного освітнього стандарту, підготовка медичної сестри передбачає необхідність 
досягнення 1-ї «інтегральної», 10-ти «загальних» i 21-ї «спеціальних (фахових) компетентностей». Крім того, окреслено програмні результати навчання медичних сестер, що включають знання та розуміння нормативних документів, інструкцій, положень, протоколів; здатність застосовувати теоретичні знання та практичні вміння; формування суджень (аналізувати, оцінювати результати, аргументувати рішення).

Дисципліна «Основи медсестринства» у медичному коледжі належить до «Циклу професійної та практичної підготовки». Вивчаючи на другому курсі навчання основи діяльності медичної сестри, студенти отримують необхідні знання, навички, уміння, готуючись до подальшої практичної діяльності. Засвоєння дисципліни завершується іспитом, спрямованим на всебічну оцінку набутих студентами знань, навичок і умінь.

Послідовне вивчення дисципліни формує у майбутніх медичних сестер холістичне бачення своєї майбутньої професії, забезпечує засвоєння студентами теоретичних знань та практичних умінь при здійсненні медсестринського процесу. На знаннях, отриманих при вивченні дисципліни «Основи медсестринства», ґрунтується вивчення таких компонентів освітньопрофесійної програми, як «Медсестринство в педіатрії», «Медсестринство в хірургії», «Медсестринство в сімейній медицині», «Анестезіологія та реаніматологія», «Медсестринство в онкології», «Медсестринство в дерматології та венерології», «Медсестринство в геронтології, геріатрії та паліативній допомозі», «Медсестринство в оториноларингології», «Медсестринство в офтальмології» тощо. Вона інтегрується з такими дисциплінами, як «Громадське здоров'я та громадське медсестринство», «Медсестринська етика та деонтологія», «Основи профілактичної медицини», «Медична та соціальна реабілітація», необхідними для досягнення необхідного освітньо-кваліфікаційного рівня молодшого спеціаліста. Відповідне оволодіння компонентами освітньо-професійної програми забезпечує розвиток кругозору, міждисциплінарного чуття, здатність до індивідуальних креативних рішень, до самонавчання, а також формування гуманістичних цінностей.

Освітній процес тісно пов'язаний з практичною діяльністю студентів. При проведенні практичних занять принцип фундаментальності освіти доповнюється принципом практичної орієнтованості та діяльнісної спрямованості студентів. Оскільки дисципліна «Основи медсестринства» $є$ початковим етапом навчання, то з метою виключення ризику для здоров'я пацієнта в основному передбачено симуляційний метод, коли студенти відпрацьовують маніпуляції у кабінетах доклінічної практики, що відображають реальні умови та імітацію робочого місця медичної сестри.

Відповідне вивчення дисципліни «Основи медсестринства» дозволяє сформувати усі десять, передбачених програмою, загальних та шістнадцять із двадцяти однієї фахових компетентностей.

Метою практичних занять кожного із чотирьох розділів навчальної програми $\epsilon$ не тільки вивчення і закріплення студентами нових знань, але й перетворення теоретичних знань у практичні уміння і навички, які сприяють формуванню компетентностей, розвивають їх комунікативні, прогностичні, гностичні якості, прагнення до самопізнання і самовдосконалення, здатність до адекватної самооцінки професійної діяльності. Так, завдання розділу 1 «Вступ до предмета «Основи медсестринства». Медсестринські теорії і процес» полягає у вивченні історії та філософії медсестринської справи в Україні та за кордоном, ознайомленні з різними моделями медсестринської справи і освоєнні медсестринського процесу, навчанні студентів техніці спілкування, сприянні формуванню власного погляду студента на професію, його ознайомлення з моральними концепціями, принципами й традиціями медсестринської справи, що дасть змогу студентам краще зрозуміти сутність майбутньої професії, та слугує підґрунтям для формування загальних (3К 1-10) та певних фахових (ФК 1-11) компетентностей. Завдання розділу 2 «Основи практичної діяльності медичної сестри. Маніпуляційна техніка» передбачає розвиток навичок та уміння виконувати різні сестринські втручання при наданні медичної допомоги, проведення санітарно-просвітницької роботи, забезпечувати належне зберігання та використання лікарських засобів, що є передумовою формування фахових (ФК 12-21) компетентностей. У розділі 3 «Основи санології» (ФК 13-16) висвітлено основні принципи здорового способу життя, можливості втручання медичної сестри задля зміцнення здоров'я хворого та збереження здоров'я здорових людей. Під час практичних занять розділу 4 «Підсумкова практика» студенти вчаться реалізовувати схему сестринського процесу як наукового підходу в наданні сестринської допомоги пацієнтам у конкретній клінічній ситуації, вдосконалити набуті у процесі вивчення дисципліни навички іуміння, тобто підвищують свою професійну компетентність. Отже, «Основи медсестринства»- це 
дисципліна, у процесі вивчення якої студент засвоює основні принципи, теорії та процедури сестринського догляду, яка висвітлює концепції структурування професійної практики, сестринського процесу на основі досліджень, зібраних протягом століть; навчає взаємодії з пацієнтами, критичного мислення, сприяє формуванню фундаментальних навичок як передумови надання широкого спектра сестринського догляду.

Висновки. 3 кожним роком зростає потреба у кваліфікованих медичних сестрах і їх внеску в справу охорони здоров'я різних груп населення, дедалі глибше усвідомлюється необхідність подальшого розвитку функцій професійної діяльності медичної сестри на різних рівнях надання медичної допомоги

\section{СПИСОК ЛІТЕРАТУРИ}

1. Компетентнісний підхід в освіті: теоретичні засади і практика реалізації : матеріали методологічного семінару 3 квіт. 2014 р., м. Київ : у 2 ч. Ч. 1 / Нац. акад. пед. наук України ; [редкол. : В. Г. Кремень (голова), В. І. Луговий (заст. голови), О. І. Ляшенко (заст. голови) та ін.]. - К. : ІН-Т обдарованої дитини НАПН України, 2014 - 370 с.

2. Криницька І. Я. Особливості професійної підготовки медичних сестер на сучасному етапі / І. Я. Криницька, М. І. Марущак, І. М. Кліщ // Вісник соціальної гігієни та організації охорони здоров'я України. - 2017. - № 4 (74). C. 84-87.

3. Філоненко М. М. Методика викладання у вищій медичній школі на засадах компетентнісного підходу : методичні рекомендації для викладачів та здобувачів та її видах. 3 огляду на це, становлення професійної компетентності медичних сестер, розвиток їх особистісних якостей, комунікативних здібностей, мотивація відбувається вже на початку оволодіння професією в процесі вивчення базових дисциплін. Компетентнісний підхід, як важливий ресурс для розвитку професійних якостей майбутніх медичних сестер, допомагає їм активізувати свій потенціал і усвідомити відповідальність за майбутню діяльність. Іншими словами, вивчення дисципліни «Основи медсестринства» формує основні компетентності, які $\epsilon$ фундаментом для подальшого успішного навчання у медичному навчальному закладі, та в майбутньому - набуття професійної майстерності.

наукового ступеня доктора філософії (PhD) BM(Ф)H3 України / М. М. Філоненко. - К., 2016. - 88 с.

4. Єрємєєва І. В. Формування професійної компетентності майбутніх медичних сестер у процесі вивчення фахових дисциплін / І. В. Єрємєєва // Магістр медсестринства. - 2015. - № 2 (14). - С. 28-30.

5. Литвинова А. Е. Компетентність медичних сестер у питанні знеболювання паліативних хворих / А. Е. Литвинова // Медсестринство. - 2018. - № 2. - С. 31-33.

6. Lejonqvist G.-B. Evaluating clinical competence during nursing education: $A$ comprehensive integrative literature review / G.-B. Lejonqvist, K. Eriksson, R. Meretoja // International Journal of Nursing Practice. - Vol. 22. Issue 2. - P. 142-151. 